\title{
SHEAR BEHAVIOR OF REINFORCED CONCRETE SLENDER BEAMS USING HIGH-STRENGTH CONCRETE
}

\author{
B.K.Kolhapure \\ Department of Civil Engineering, P.D.A. College of Engineering, Gulbarga (India) \\ kolhapurebk@yahoo.com
}

\begin{abstract}
An experimental investigation is carried out on Nine Slender HSC beams with constant size $125 \mathrm{~mm} \times 130 \mathrm{~mm}$ and effective length $900 \mathrm{~mm}$ by varying ( $i$ ) The longitudinal reinforcement ratio and (ii) the web reinforcement ratio were casted and tested to understand the shear behavior of the beams with minimum web reinforcement as per IS CODE and ACI CODE and maximum web reinforcement. The load-deflection behavior and the failure pattern of the beams, ultimate shear strength are studied with varying longitudinal reinforcement and varying shear reinforcement. The experimental results obtained are compared with the theoretical values as per code. Based on these observations, it can be concluded that, there are many parameters influencing the shear behavior of RC beams such as shear span to depth ratio (a/d ratio>2), concrete grade, depth of the beam, the percentage of the longitudinal reinforcement and shear reinforcement. It can be concluded that, the shear failure is brittle, sudden and very explosive. As the spacing of shear reinforcement reduced $(75 \mathrm{~mm})$ the load carrying capacity increased and as the spacing of shear reinforcement increased $(225$, $300 \mathrm{~mm})$ the load carrying capacity decreased. Shear failure is characterized by small deflection, lack of ductility and catastrophic failure.
\end{abstract}

Keywords: High strength concrete, shear span to depth ratio, failure pattern, ultimate shear capacity, codal provisions.

\section{INTRODUCTION}

In the past decade there has been rapid growth in high strength concrete (HSC) the ACI defines HSC as concrete with a compressive strength greater than $41 \mathrm{MPa}$. The applications of HSC have increased as a result of recent developments in material technology and a demand for HSC [1].

Manufacture of HSC involves making optimal use of the basic ingredients that constitute Normal Strength Concrete (NSC) by varying the proportions of cement, water, aggregates and admixtures. Fly ash and silica fume are the most commonly used mineral admixtures in HSC. Some of the mechanical properties are limited by our codes by a maximum numerical value, whereas many of the properties are defined by an expression as a function of grade of concrete. This situation leads us to various anomalous results if grade of concrete used in design is higher than the one corresponding to which the values of certain mechanical properties of HSC are not allowed to increase [2]. HSC finds application in different structures like oil drilling rigs, diaphragm walls, pre-stressed concrete piles, columns of high rise buildings, transfer beams of multi- storey buildings and large span bridges [3].

\subsection{Shear Reinforcement:}

Shear reinforcement is usually provided in the form of stirrups to hold the longitudinal reinforcement and also to take the shear and to arrest the development of the diagonal tension cracking to which the structure is subjected. Even if shear reinforcement is not required, a minimum has to be provided as per IS: $456[18]$.

\subsection{Minimum Shear Reinforcement:}

The main reasons for providing minimum shear reinforcement in RC beams are as follows [9][10]:

a) To avoid brittle shear failure after diagonal shear crack.

b) To provide reserve strength even after the diagonal shear crack formation.

c) To redistribution of the stresses in the region of shear span.

d) To impart ductility to the beam before shear failure.

e) To limit the diagonal crack width well within the limits and to provide reserve deflection.

Most of the codes gives the expressions similar based on concrete strength and yield strength of web reinforcement neglecting many parameters such as a/d ratio, longitudinal reinforcement, type of load and amount of web reinforcement. Understanding the strength and deformational behavior of beams with HSC provided with minimum reinforcement becomes very important before it is put in to practice [11][12]. 


\subsection{The Mechanism of Shear Resistance in Reinforced Concrete Beams with Web Reinforcement:}

In addition to the bond force resisted by the combination of aggregate interlock, dowel and the flexural action of the cantilever, another bond force can be sustained by what is traditionally termed truss action. In this truss the cantilevers act as a diagonal compression members [2].

- A stirrup can effectively support a longitudinal bar that is being crossed by a flexural shear cracks close to a stirrup, contribute to the strength of the shear mechanisms improving the contribution of the dowel action.

- Suppressing flexural tensile stresses in the cantilever blocks by means of the diagonal compression force resulting from truss action.

- Limiting the opening of diagonal cracks within the elastic range thus enhancing and preserving shear transfer by aggregate interlock.

- Providing confinement when the stirrups are sufficiently closely spaced thus increasing the compression strength of localities particularly affected by the arch action Preventing the breakdown of bond when splitting cracks develop in anchorage zones because of dowel and anchorage forces For rectangular beams, after an inclined crack has formed, the proportion of the shear force transferred by the various mechanisms is as 20 to 40 percent by the uncracked concrete of compression zone, 33 to 50 percent by interlocking action of aggregates; and 15 to 25 percent by dowel action. Meanwhile, in a relatively short beam, the load is transferred directly from the loading points to supports owing to arch action[7]

- It may be said that suitably detailed web reinforcement will preserve the integrity therefore the strength of the previously defined beam mechanism allowing additional shear forces to be resisted by the truss mechanism[3]

- The span-to-height ratio of the analogous arch is approximately equal to the shear span-to-depth ratio. The strength of the compression strut is closely related to the compressive strength of concrete and the area of tension reinforcement [8].

\section{OBJECTIVES OF PRESENT WORK:}

To study the shear behavior of HSC slender beams with different web reinforcement

1. To know the influence of transverse reinforcement on HSC slender beams.

2. To study the effect of $\mathrm{a} / \mathrm{d}$ radio on the load carrying capacity of the beam.

3. To study the effect of percentage of longitudinal steel on the shear capacity

4. To compare the experimental values with the codes.

\section{EXPERIMENTAL STUDY:}

Preliminary tests conducted on the ingredients are tabulated in table No :(1). The Mix Proportions for M60 obtained by ACI 318-2002. are shown in table (2)

Table 1 Test Results on ingredients of Concrete

\begin{tabular}{|l|l|l|}
\hline SL.NO. & MATERIALS & TESTS CONDUCTED \\
\hline \multirow{4}{*}{1.} & CEMENT & 53 Grade OPC as per IS 12269-1970 \\
\cline { 2 - 3 } & Initial setting time & $50 \mathrm{~min}$ \\
\cline { 2 - 3 } & Final setting time & $550 \mathrm{~min}$ \\
\cline { 2 - 3 } & Normal consistency & $34 \%$ \\
\cline { 2 - 3 } & Specific gravity cement & 3.0 \\
\cline { 2 - 3 } & Compressive & $51 \mathrm{Mpa}$ \\
\hline 2. & COARSE AGGREGATE & $\begin{array}{l}\text { Crushed granite, passing through 12.5 mm and retained on 4.75mm sieve } \\
\text { specific gravity =2.66, as per IS 383-1978 }\end{array}$ \\
\hline 3. & FINE AGGREGATE & River sand, zone II, specific gravity =2.66 as per IS 383-1978 \\
\hline 4. & WATER & Potable water as per IS 456-2000[17] \\
\hline 5. & SUPER PLASTICIZER & CONPLAST SP 430 as per IS 9103-1999 \\
\hline
\end{tabular}

Table 2: Mix Proportion for M60

\begin{tabular}{|l|l|l|l|l|l|l|}
\hline Mix & Cement & $\begin{array}{l}\text { Fine } \\
\text { aggregate }\end{array}$ & $\begin{array}{l}\text { Coarse } \\
\text { aggregate }\end{array}$ & Water & $\begin{array}{l}\text { Super } \\
\text { plasticizer }\end{array}$ & $\begin{array}{l}\text { Cube 28 days Compressive Strength } \\
\left(\mathrm{N} / \mathrm{mm}^{2}\right)\end{array}$ \\
\hline M60 & 1 & 0.47 & 1.95 & 0.3 & 1.35 & 67.5 \\
\hline
\end{tabular}




\section{CASTING AND TEST SPECIMENS OF SPECIMEN:}

In the present work, 09 HSC slender beams were casted and tested. The beams were with web reinforcement in accordance with IS456[17], ACI 318[16], with concrete strength of $60 \mathrm{Mpa}$ (M60). The cross sectional dimension of the beam was $125 \mathrm{~mm} \times 130 \mathrm{~mm}$ and effective length $900 \mathrm{~mm}$. For this the longitudinal reinforcement and the shear reinforcement were kept varying, but the compressive strength (grade) of concrete, a/d ratio and effective length were kept as constant. Four point loading was applied. The incremental load was applied and corrospoding deflections were noted under the point loads and at the centre

\section{RESULTS AND DISCUSSION:}

The load at which the first visible crack appeared was taken as " cracking load $\left(\mathrm{P}_{\mathrm{cr}}\right.$ )" and the load at which the beam failed completely was taken as "ultimate load $\left(\mathrm{P}_{\mathrm{u}}\right)$ ". The details of beam specification and experimental test results are shown in table (3), the load v/s deflection for different beam specimen are shown in graph (1) to (3). The failure pattern of the HSC beams are shown in figure(1)

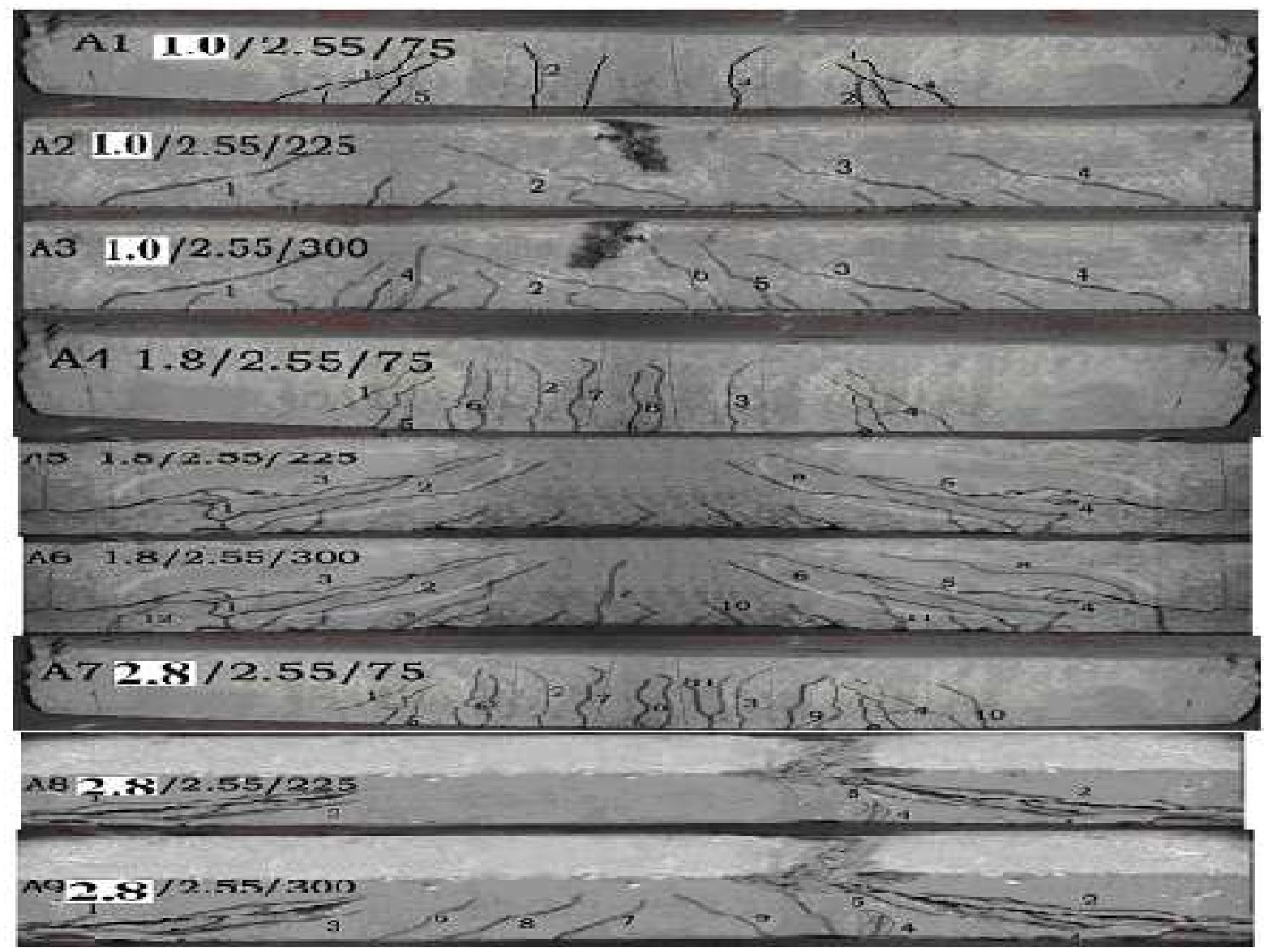

Figure 1 Failure Patterns of Hsc Beams.

In Figure (1): First Character indicates Beam Specification, Second percentage reinforcement, Third a/d ratio, Fourth stirrup spacing.

Table 3: Details beam specification and experimental Test Results

\begin{tabular}{|l|l|l|l|l|l|l|l|l|l|l|l|}
\hline Sr. & BEAM & le $\mathrm{mm}$ & $\begin{array}{l}28 \\
\text { day } \\
\text { Mpa }\end{array}$ & a/d & $\rho \%$ & $\begin{array}{l}\text { Pcr } \\
\text { KN }\end{array}$ & $\begin{array}{l}\tau \text { CR= } \\
\text { Pcr/2b } \\
\text { d }\end{array}$ & $\begin{array}{l}\text { Pu } \\
\text { KN }\end{array}$ & $\begin{array}{l}\tau \text { u }= \\
\text { Pu/2bd }\end{array}$ & $\begin{array}{l}\text { S } \\
(\mathrm{mm})\end{array}$ & $\begin{array}{l}\text { MODE OF } \\
\text { FAILURE }\end{array}$ \\
\hline A & A1 & 900 & 66.7 & 2.55 & 0.8 & 34.05 & 1.04 & 120 & 3.6 & 75 & Flexure \\
\hline
\end{tabular}




\begin{tabular}{|l|l|l|l|l|l|l|l|l|l|l|l|}
\hline & A2 & 900 & 67.0 & 2.55 & 0.8 & 26.87 & 0.83 & 96 & 2.96 & 225 & Flexure \\
\hline & A3 & 900 & 68.1 & 2.55 & 0.8 & 22.75 & 0.70 & 80 & 2.45 & 300 & Flexure \\
\hline B & A4 & 900 & 66.0 & 2.55 & 1.8 & 35.46 & 1.09 & 125 & 3.82 & 75 & Shear \\
\hline & A5 & 900 & 68.0 & 2.55 & 1.8 & 29.69 & 0.91 & 104 & 3.21 & 225 & Shear \\
\hline & A6 & 900 & 64.2 & 2.55 & 1.8 & 25.14 & 0.77 & 90 & 2.71 & 300 & Shear \\
\hline C & A7 & 900 & 66.0 & 2.55 & 3.2 & 42.32 & 1.3 & 149 & 4.48 & 75 & Shear \\
\hline & A8 & 900 & 67.6 & 2.55 & 3.2 & 34.21 & 1.05 & 120 & 3.59 & 225 & Shear \\
\hline & A9 & 900 & 66.5 & 2.55 & 3.2 & 30.82 & 0.94 & 110 & 3.31 & 300 & Shear \\
\hline
\end{tabular}

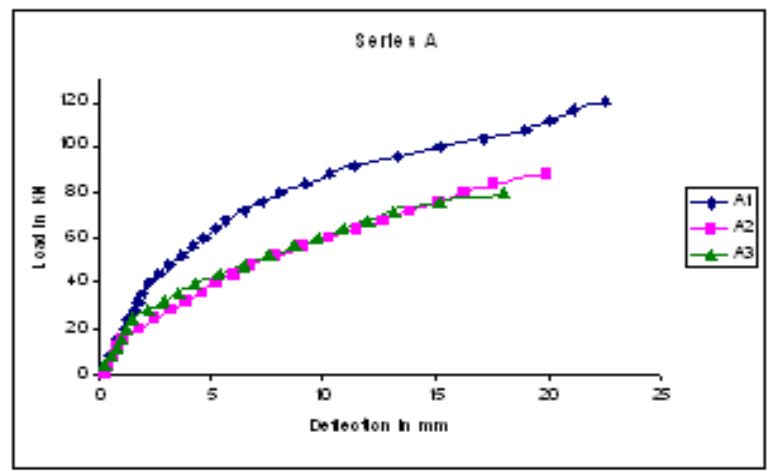

Graph 1 Load V/s Defln for series A beams:

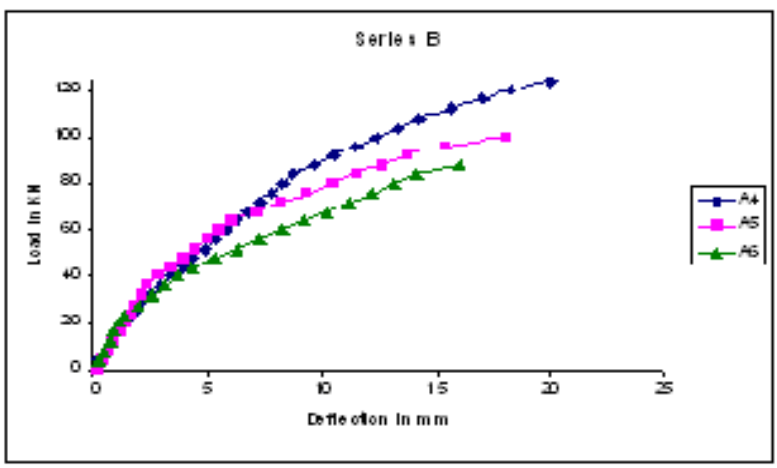

Graph 2 Load V/s Deflection for series B beams

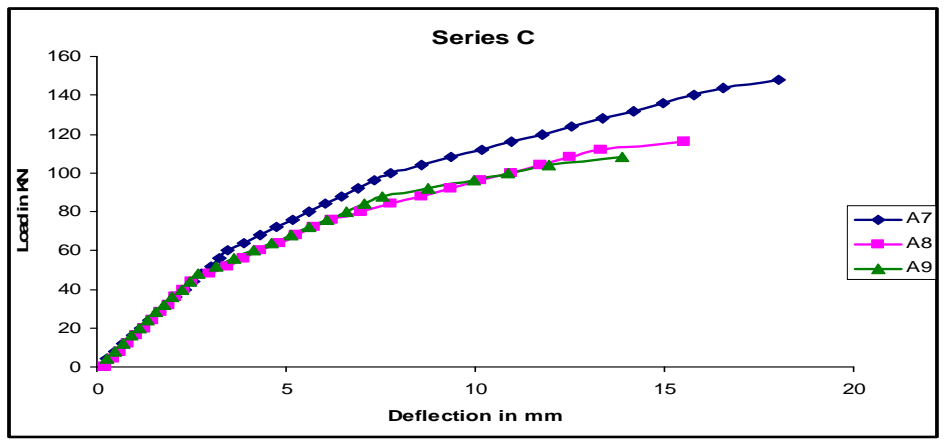

Graph 3 Load V/s Deflection for HSC series C beams

From the graph (1) to (3) it can be seen that as the spacing of shear reinforcement decreased the ductility increased and also the load carrying capacity and as the percentage of longitudinal steel increased the load carrying capacity increased and vice versa. Shear failure is very sudden and brittle but flexural failure of beams is ductile.

\section{ULTIMATE SHEAR STRENGTH PREDICTED BY DIFFERENT CODES:}

\subsection{Shear Design by ACI Code Equation [16]-}

ACI CODE 318 (1989) - (a / d > = 2.5)

$\mathrm{V}_{\mathrm{u}}=\left(0.158 \operatorname{sqrt}\left(\mathrm{f}_{\mathrm{c}}^{\prime}\right)+17.45 \rho\left(\mathrm{V}_{\mathrm{U}} \mathrm{d} / \mathrm{M}_{\mathrm{u}}\right) \mathrm{b}_{\mathrm{w}} \mathrm{d}+\right.$ $\left(\mathrm{A}_{\mathrm{v}} \mathrm{f}_{\mathrm{sv}} \mathrm{d} / \mathrm{S}\right)$ bw and $\mathrm{d}=$ Width and depth of Effective cross section in $\mathrm{mm}$. $\mathrm{M}_{\mathrm{u}}$ and $\mathrm{V}_{\mathrm{u}}$ - Factored moment and Factored shear force at Cross section.

$\rho$ - Longitudinal Reinforcement Ratio.

$\mathrm{f}_{\mathrm{c}}$, - Compressive strength of concrete at 28 days in MPa. $\mathrm{S}=$ spacing of shear reinforcement.

\subsection{Indian Code Is 456-2000[17]}

According to Indian code equation the shear strength of concrete members is given by following equation.

$\mathrm{Vu}=\mathrm{b}_{\mathrm{w}} \mathrm{d} 0.85 \operatorname{sqrt}\left(0.8 \mathrm{f}_{\mathrm{ck}}\right)(\operatorname{sqrt}(1+5 \beta)-1) / 6 \beta+(\mathrm{Av}$ $\left.f_{s v} d / S\right)$

$b_{w}$ and $d=$ Width and depth of Effective cross section in $\mathrm{mm}$ 
$\mathrm{fc}^{\prime}$ - Cube Compressive strength of concrete at 28 days in $\mathrm{MPa}$.

$\mathrm{S}=$ spacing of shear reinforcement.

$\beta=\left(0.8 \mathrm{f}_{\mathrm{ck}} /\left(689 \mathrm{~A}_{\mathrm{S}} / \mathrm{bw} \mathrm{d}\right)\right)>=1$

Using the above equations the ultimate shear strength of beams were calculated. The ratio of experimental shear to the calculated shear was worked out. The results obtained by ACI
CODE 318 were quite satisfactory as compared to other codes. So the values of ultimate shear strength from the experimental investigation have been compared with ACI code.

The Comparative results of the Experimental loads and theoretical loads by Aci 318-2002[16] are studied as shown in Table(4).

Table 4: Details of Experimental Load and Theoretical Loads

\begin{tabular}{|l|l|l|l|}
\hline $\begin{array}{l}\text { BEAM } \\
\text { SERIES }\end{array}$ & $\begin{array}{l}\text { EXPERIMENTAL LOAD } \\
\text { V(EXP) inKN(Pu/2) }\end{array}$ & $\begin{array}{l}\text { THEORETICAL LOAD ACI 318 } \\
\text { code V(THE) in KN }\end{array}$ & $\begin{array}{l}\text { RATIO (EXP/ THE) } \\
\text { V(EXP)/V(THE) }\end{array}$ \\
\hline A1 & 60 & 44 & 1.36 \\
\hline A2 & 48 & 28 & 1.71 \\
\hline A3 & 40 & 26 & 1.54 \\
\hline A4 & 62.5 & 46 & 1.36 \\
\hline A5 & 52 & 29 & 1.79 \\
\hline A6 & 45 & 27 & 1.67 \\
\hline A7 & 74.5 & 47 & 1.59 \\
\hline A8 & 60 & 52 & 1.15 \\
\hline A9 & 55 & 29 & 1.89 \\
\hline
\end{tabular}

\section{CONCLUSIONS}

The following conclusions were made from the experimental investigation:

1. Mix proportion for high strength concrete $\left(\mathrm{M}_{60}\right)$ was obtained by using chemical admixture, the average 28 days strength was found to be $68 \mathrm{mpa}$.

2. As the spacing of shear reinforcement reduces to $75 \mathrm{~mm}$ the load carrying capacity increased and as the spacing of shear reinforcement increased to $225 \mathrm{~mm}$ and $300 \mathrm{~mm}$ the load carrying capacity decreased. Shear failure is characterized by small deflection lack of ductility and catastrophic failure.

3. As the percentage of longitudinal steel increased from $1 \%, 1.8 \%$ and $2.8 \%$ the load carrying capacity increased. But for higher spacing of shear reinforcement it was less significant. Hence it shows that the dowel action increases significantly as the spacing of the shear reinforcement decreases. As the pressing down of steel is reduced and confinement of longitudinal steel is increased.

4. As the shear span to depth ratio $(\mathrm{a} / \mathrm{d})$ is 2.55 , it was shear tension failure. But this doesn't hold good for shear steel spacing of $75 \mathrm{~mm}$ were its failure is in flexure rather than shear. Smaller a/d ratio results in arching action and hence higher shear strength but higher $\mathrm{a} / \mathrm{d}$ ratio results in beam action resulting lesser shear capacity.

5. The minimum shear reinforcement specified in different codes is inadequate and could be modified. The shear equation cannot be applied to all the different cross sections and the grade of the concrete; the depth parameters and the strain in steel etc. are not included in the codal provision.

\section{REFERENCES}

[1]. ACI 363R-92 (Reapproved 1997) State-of-the-Art Report on High-Strength Concrete, Reported by ACI Committee 363. [2]. American concrete institute. ACI concrete mix design, ACI 211, revision 613-54.

[3]. AASHTO ,' code for minimum shear reinforcement "

[4]. S.Sarkar, O.Adwan, B.Bose, "Shear stress distribution and failure mechanics of high-strength reinforced concrete beams" Materials and Structures, V32, No.216, March 1999, pp 112116.

[5]. S.V.T.J.Perera, Lam Huu Quang, Hiroshi MutsuyoshI and Ha Minh, "Shear Behavior of Reinforced Concrete Beams Using High-Strength Concrete.

[6]. Satish.B.DesaI, "Influence of constituents of concrete on its tensile strength and shear strength," ACI Structural Journal, Jan-Feb2004, Pg 29-38.

[7]. Mohammad Musa Megdadi, "Shear and Flexural Behaviour of High Strength Concrete Beams with Large Span to Depth Ratio".

[8]. Raghu S.Pendyala and Priyan Mendis, "Experiment Studies on Shear Strength of High Strength Concrete Beams," ACI Structural Journal/july-august 2000, pp $564-571$.

[9]. Guney Ozcebe, Ugur Ersoy, and Tugrul Tankut et al, "Evaluation of Minimum Shear Reinforcement Requirements 
for Higher Strength Concrete," ACI Structural Journal/May-. June 1999 pp 361-368.

[10]. Mark k. Johnson and Julio A. Ramirez, "Minimum Shear Reinforcement in Beams with Higher Strength Concrete," ACI Structural Journal/July-Aug 1989 pp 376-382.

[11]. Young-soo Yoon, William D. Cook and Denis Nitchell, "Minimum Shear Reinforcement in Normal, Medium, and High-Strength Concrete Beams," ACI Structural Journal/SeptOct 1996 pp 576- 584.

[12]. Dino Angelakos, Evan C. Bentz and Michael P. Collins, "Effect of Concrete Strength and Minimum Stirrups on Shear Strength of Large Members," ACI Structural Journal/MayJune 2001 pp290-300

[13]. ASTM - C $618-93$.

[14]. N.Subramanian, "Shear strength of HSRC Beams", (codal provision review), Indian concrete Journals, march 2003, pp 114-122.

[15]. Prodromos D Zararis,"shear strength \& min shear reinforcement", ACI structural journals, June 2003, pp355455.

[16]. ACI committee 318, "Building code requirements for structural concrete (ACI 318-05) and commentary (318-05)', American concrete institutes, Farmington hills, MI, 2005, PP430.

[17]. IS:456-2000, “Indian Standards for Plain and Reinforced Concrete. 